\title{
Biosurfactant from endophytic Bacillus pumilus 2A: physicochemical characterization, production and optimization and potential for plant growth promotion
}

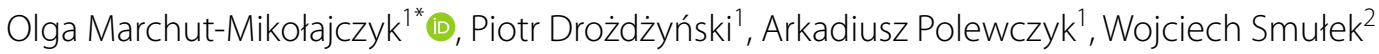
and Tadeusz Antczak ${ }^{3}$

\begin{abstract}
Background: Microbial surfactants called biosurfactants, thanks to their high biodegradability, low toxicity and stability can be used not only in bioremediation and oil processing, but also in the food and cosmetic industries, and even in medicine. However, the high production costs of microbial surfactants and low efficiency limit their largescale production. This requires optimization of management conditions, including the possibility of using waste as a carbon source, such as food processing by-products. This papers describes the production and characterization of the biosurfactant obtained from the endophytic bacterial strain Bacillus pumilus 2A grown on various by-products of food processing and its potential applications in supporting plant growth. Four different carbon and nitrogen sources, $\mathrm{pH}$, inoculum concentration and temperature were optimized within Taguchi method.
\end{abstract}

Results: Optimization of bioprocess within Taguchi method and experimental analysis revealed that the optimal conditions for biosurfactant production were brewer's spent grain ( $5 \% \mathrm{w} / \mathrm{v})$, ammonium nitrate ( $1 \% \mathrm{w} / \mathrm{v})$, pH of $6,5 \%$ of inoculum, and temperature at $30^{\circ} \mathrm{C}$, leading to $6.8 \mathrm{~g} / \mathrm{L}$ of biosurfactant. Based on gas chromatography-mass spectrometry and Fourier transform infrared spectroscopy analysis produced biosurfactant was determined as glycolipid. Obtained biosurfactant has shown high and long term thermostability, surface tension of $47.7 \mathrm{mN} / \mathrm{m}$, oil displacement of $8 \mathrm{~cm}$ and the emulsion index of $69.11 \%$. The examined glycolipid, used in a concentration of $0.2 \%$ significantly enhanced growth of Phaseolus vulgaris L. (bean), Raphanus L. (radish), Beta vulgaris L. (beetroot).

Conclusions: The endophytic Bacillus pumilus 2A produce glycolipid biosurfactant with high and long tem thermostability, what makes it useful for many purposes including food processing. The use of brewer's spent grain as the sole carbon source makes the production of biosurfactants profitable, and from an environmental point of view, it is an environmentally friendly way to remove food processing by products. Glycolipid produced by endophytic Bacillus pumilus 2A significantly improve growth of Phaseolus vulgaris L. (bean), Raphanus L. (radish), Beta vulgaris L. (beetroot). Obtained results provide new insight to the possible use of glycolipids as plant growth promoting agents.

Keywords: Food industry wastes, Biosurfactant, Optimization, Endophytes, Bacillus pumilus 2A, Plant-growth promotion

\footnotetext{
*Correspondence: olga.marchut-mikolajczyk@p.lodz.pl

1 Institute of Molecular and Industrial Biotechnology, Faculty

of Biotechnology and Food Science, Lodz University of Technology, Stefanowskiego 4/10, 90-924 Łódź, Poland

Full list of author information is available at the end of the article
}

\section{Background}

Surfactants are amphiphilic compounds composed of hydrophilic and hydrophobic groups. These molecules can reduce the surface and interfacial tension between

(C) The Author(s) 2021. This article is licensed under a Creative Commons Attribution 4.0 International License, which permits use, sharing, adaptation, distribution and reproduction in any medium or format, as long as you give appropriate credit to the original author(s) and the source, provide a link to the Creative Commons licence, and indicate if changes were made. The images or other third party material in this article are included in the article's Creative Commons licence, unless indicated otherwise in a credit line to the material. If material is not included in the article's Creative Commons licence and your intended use is not permitted by statutory regulation or exceeds the permitted use, you will need to obtain permission directly from the copyright holder. To view a copy of this licence, visit http://creativeco mmons.org/licenses/by/4.0/. The Creative Commons Public Domain Dedication waiver (http://creativecommons.org/publicdomain/ zero/1.0/) applies to the data made available in this article, unless otherwise stated in a credit line to the data. 
liquids, solids and gases. Due to their properties and chemical structure, surfactants are widely used as emulsifiers, detergents, dispersants, semiconductors and wetting agents, which has led to the production of over 15 million tons of surfactants annually [1-5]. As a result of their wide use, surfactants are largely released into the environment, which can cause contamination and pose a threat to all living organisms, including humans. These compounds move along with the movements of air masses over long distances and along with its variable humidity they can settle in soil and water causing their contamination and at the same time threatening penetration into the trophic chain and causing adverse changes. In the aquatic environment, surfactants increase the rate of eutrophication by limiting the concentration of dissolved oxygen. The negative effect of surfactants on humans has been proved-among others endocrine disorders, skin irritation, and also trigger allergies $[6,7]$.

Microbial surface-active agents called biosurfactants, provide a valuable alternative for synthetic surfactants. These compounds are produced by both bacteria and fungi. Based on the chemical composition, biosurfactants can be classified as lipopeptides and lipoproteins, glycolipids, phospholipids, fatty acids, polysaccharide-lipid complexes and polymeric surfactants [8,9]. Compared with chemically synthesized surfactants, microbial surface active compounds are characterized by higher biodegradability, lower toxicity as well as better stability and foaming properties in different environmental conditions $[8,10,11]$. These characteristics have led to a growing interest in biosurfactant for use not only in bioremediation and oil processing, but also in the food and cosmetic industries and even in medicine [12]. Furthermore, unlike their chemical counterpart produced based on fossil fuels, biosurfactants can be obtained using waste materials, including agricultural waste. The use of renewable raw materials and fossil resources to produce new products is a pillar of a circular economy. Examples of products based on this type of raw material are biological surface active compounds $[5,13]$. Agricultural waste and food processing by-products can serve as a carbon source for the processes of microbial biosurfactant production, due to its availability and low costs (they constitute $30-50 \%$ of municipal solid wastes) [13]. Simultaneously, this may generate an environmental friendly method of waste disposal [14]. Production of biosurfactants on cheap agricultural waste (wheat bran, waste cooking oil, grease waste) has been reported $[15,16]$.

Also, Moshtagh et al. [14] investigated the possibility of biosurfactant production by Bacillus subtilis N3-1P using brewery waste. However, high costs of the production of microbial surfactants and low yield limit their large scale production. This requires optimization of culturing conditions and large scale production, including the use of waste as a carbon source [17].

Endophytic microorganisms are bacteria and fungi that live in plant tissues without causing any negative changes in the host's organism (physiological, epidemiological or pathogenic). Endophytic microbes are ubiquitous-they inhabit the tissues of all plant species [18-20]. It is known that endophytic microorganisms can stimulate plant growth, produce biologically active compounds (antibiotics, biosurfactants, phytohormones), increasing the host's resistance to stressful environmental conditions, increasing resistance to pathogens and pests [21].

In our previous work [20], we have described the potential of endophytic Bacillus pumilus 2A, isolated from Chelidonium majus L. herb, for biosurfactant production. We also showed the positive effect of biosurfactant on plant growth in a polluted environment. The aim of the research was to optimize the production of biosurfactant by endophytic Bacillus pumilus 2A with the use of various types of food processing by-products (spent grain, beet pulp, molasses, used cooking oil), characterizing its chemical structure and use as a plant growth promoting agent. In order to obtain the highest possible efficiency of the most stable production of biosurfactants, a series of experiments was conducted based on the Taguchi experiment design.

\section{Materials and methods \\ Biological material}

The bacterial endophytic biosurfactant producer Bacillus pumilus 2A was previously isolated from Chelidonium majus L. herb and deposited in the Institute of Molecular and Industrial Biotechnology collection. Preparation and isolation of the endophytic strain from Chelidonium majus L. was carried out according to the previously described procedures [20]. In short, the plant material was carefully excavated from the area adjacent to the A1 motorway near Stryków in Poland and transported to a laboratory in plastic containers, where it was rinsed under running water. Then surface sterilization was performed of healthy plants parts with use of $1 \%$ sodium hypochlorite, $70 \%$ ethanol and sterile water. Then plants parts were cut into small pieces $(\sim 1 \mathrm{~cm})$ and placed on the sterile agar NB medium. The plates were incubated at $30{ }^{\circ} \mathrm{C}$ for 5 days. The pure colonies were selected, picked up and transferred to slant specific media (LB, Chapekdox) and screened for degradation and emulsifying activity [20].

After isolation, pure culture of Bacillus pumilus 2A was preserved in $20 \%$ glycerol at $-80^{\circ} \mathrm{C}$. This endophytic bacteria, among other eleven isolates had the highest emulsifying activity and emulsion index [20]. 
Table 1 Design of experiment with Taguchi method: selected factors and designated levels

\begin{tabular}{llllll}
\hline Symbol & Factor & Level & & L3 & L4 \\
\cline { 3 - 6 } & & L1 & Waste cooking oil & Molasses & Beet pulp \\
\hline A & Carbon source & Brewer's spent grain & Ammonium nitrate & Ammonium sulfate & Corn soak \\
B & Nitrogen source & Monosodium glutamate & 6 & 7 & 8 \\
C & $\mathrm{pH}$ & 5 & 5 & 7 & 9 \\
$D$ & Inoculum $(\%)$ & 3 & 30 & 37 & 45 \\
E & Temperature $\left({ }^{\circ} \mathrm{C}\right)$ & 20 & 5 & 7 \\
\hline
\end{tabular}

\section{Substrate for optimization of biosurfactant production}

For optimization of biosurfactant production, four different carbon sources: beet pulp (Total sugars 51.5\%; Lipids 8.6\%; Protein 25.7\%; Mineral elements 3.5\%; Ash $2.9 \%$ of dry weight) molasses (Lipids $0.7 \%$; Proteins $2.1 \%$; Total sugars 49.5\%; Ash 8.5\%); brewer's spent grain (Total sugars 49.2\%; Lipids 7.65\%; Protein 29.8\%; Mineral elements $4.2 \%$; Ash $2.8 \%$ of dry weight) and waste cooking oil (Palm oil 50\%, Palmitic acid 40\%, Oleic acid 10\%, contain $\omega-6$ polyunsaturated acids) were used. Beet pulp and molasses were obtained from Polish National Sugar Company factory in Dobrzelin (Poland). Brewery spent grain as a by-product of breweries was donated from SULIMAR Ltd. Company and waste cooking oil was obtained from local restaurants in Lodz, Poland. All of used substrates were stored at $4{ }^{\circ} \mathrm{C}$ until needed.

\section{Inoculum}

Bacillus pumilus 2A strain was stored on agar slopes made of solid "A" medium with the following composition $(\mathrm{g} / \mathrm{L}): 2.0$ glucose, 2.0 yeast extract, 1.5 anhydrous $\mathrm{Na}_{2} \mathrm{HPO}_{4}, 2.5 \mathrm{NH}_{4} \mathrm{Cl}, 25$ agar at $-20^{\circ} \mathrm{C}$ [20]. To prepare inoculum one loop of bacterial biomass from slants was suspended in a $500 \mathrm{~mL}$ flask containing $40 \mathrm{~mL}$ of nutrient broth medium of the following composition: $(\mathrm{g} / \mathrm{L}) 15.0$ peptones, 3.0 yeast extract, $6.0 \mathrm{NaCl}, 1.0 \mathrm{D}(+)$ glucose. Before sterilization by autoclaving $(12 \mathrm{lC}, 15 \mathrm{~min}) \mathrm{pH}$ of the nutrient medium was adjusted to 7.0. The bacteria were cultured in the Infors incubator shaker for $24 \mathrm{~h}$ at $30{ }^{\circ} \mathrm{C}, 180 \mathrm{rpm}$. After $24 \mathrm{~h}$ optical density of the culture media was measured. For the biosurfactant production different concentrations of inoculum $\left(\mathrm{OD}_{600}=0.6\right)$ was used.

\section{Biosurfactant production}

Endophytic bacteria were inoculated into 1-L Erlenmeyer flasks containing $350 \mathrm{ml}$ of the mineral medium previously described by Marchut-Mikołajczyk et al. [22]. Biosurfactant production was conducted for 10 days on a rotary shaker $(180 \mathrm{rpm})$, at $30{ }^{\circ} \mathrm{C}$. Different carbon and nitrogen sources ( $5 \% \mathrm{w} / \mathrm{v}$ and $1 \% \mathrm{w} / \mathrm{v}$, respectively), $\mathrm{pH}$ of
Table 2 Design summary-Taguchi orthogonal array table of $\operatorname{Lg}\left(5^{4}\right)$ for experimental conditions

\begin{tabular}{|c|c|c|c|c|c|}
\hline Run & $\begin{array}{l}\text { Carbon } \\
\text { source }\end{array}$ & $\begin{array}{l}\text { Nitrogen } \\
\text { source }\end{array}$ & $\mathrm{pH}$ & Inoculum (\%) & $\begin{array}{l}\text { Temperature } \\
\left({ }^{\circ} \mathrm{C}\right)\end{array}$ \\
\hline 1 & L3 & L1 & L3 & $\llcorner 4$ & L2 \\
\hline 2 & L1 & L1 & L1 & L1 & L1 \\
\hline 3 & L2 & L2 & L1 & $\llcorner 4$ & L3 \\
\hline 4 & L1 & L2 & L2 & L2 & L2 \\
\hline 5 & L4 & L1 & $\llcorner 4$ & L2 & L3 \\
\hline 6 & L3 & L3 & L1 & L2 & $\llcorner 4$ \\
\hline 7 & L4 & L2 & L3 & L1 & $\llcorner 4$ \\
\hline 8 & L1 & L3 & L3 & L3 & L3 \\
\hline 9 & L2 & L4 & L3 & L2 & L1 \\
\hline 10 & L3 & L2 & $\llcorner 4$ & L3 & L1 \\
\hline 11 & L1 & L4 & L4 & $\llcorner 4$ & $\llcorner 4$ \\
\hline 12 & L4 & L4 & L1 & L3 & L2 \\
\hline 13 & L3 & L4 & L2 & L1 & L3 \\
\hline 14 & L2 & L1 & L2 & L3 & $\llcorner 4$ \\
\hline 15 & $\llcorner 4$ & L3 & L2 & $\llcorner 4$ & L1 \\
\hline 16 & L2 & L3 & $\llcorner 4$ & L1 & L2 \\
\hline
\end{tabular}

medium, temperature and inoculum concentration were used according to the experimental design presented in Tables 1 and 2. Medium without inoculation was used as a negative control.

\section{Design of experiments}

In order to optimize the process of biosurfactant production by Bacillus pumilus 2A Taguchi method was used. A L16 orthogonal array composed of 16 experimental setups was used. We have investigated the effect of five factors and their impacts in four different levels, (Tables 1 , 2). In order to reduce experimental errors each experiment was repeated three times.

The indexes of 1,2, 3 and 4 indicate the levels of the factors, while symbol $\mathrm{L}$ is the abbreviation of level. The samples were prepared according to the orthogonal array of L16 conditions. The aim of optimization was to select such levels of input factors that would ensure the highest amount of effective and stable biosurfactant. Therefore 
the response of the system was defined as emulsifying activity $\left(\mathrm{OD}_{500}\right)$, emulsion index (IE24), and the amount of biosurfactant. Experiments were repeated three times for each setup to avoid systematic errors. Parameters with the highest desired value were adopted and the $\mathrm{S} / \mathrm{N}$ ratio (controllable factors/confounding factors, ETA) was calculated using the formula:

$$
(S / N)_{H B}=-10 \log \left[\left(\frac{1}{n}\right) \sum\left(\frac{1}{y_{i}^{2}}\right)\right]
$$

where $\mathrm{i}$-number of measurements, $\mathrm{n}$-number of measurements for a specific measurement, $y$-measured feature.

\section{Biosurfactant isolation and purification}

In order to produce biosurfactant, the culture broth was centrifuged $\left(10000 \mathrm{rpm}, 4{ }^{\circ} \mathrm{C}, 20 \mathrm{~min}\right)$. Obtained supernatant was acidified with $6 \mathrm{M} \mathrm{HCl}$ to $\mathrm{pH} 2$ and left overnight in refrigerator $\left(4{ }^{\circ} \mathrm{C}\right)$. Then the liquid was centrifuged again at the conditions mentioned above. Supernatant was discarded and the precipitate was dissolved in $0.1 \mathrm{M} \mathrm{NaHCO}_{3}$ and lyophilized. Then lyophilized samples were extracted overnight with chloroform and methanol mixture $(2: 1)$. The solvent mixture was evaporated in a vacuum evaporator, and the extracted biosurfactant was collected [20, 23]. To assess the best conditions for biosurfactant production by Bacillus pumilus 2A, obtained extracted biosurfactants were weighed. The yield of biosurfactant production was calculated by dividing the obtained mass of the dried product by the total volume of the crude biosurfactant solution.

\section{Characterization of biosurfactant}

Carbohydrate and protein content was evaluated with phenol and sulphuric acid method and Bradford method, respectively [24, 25]. Fourier transform infrared spectrometry analysis was performed on a Thermo Scientific NICOLET 6700 FTIR spectrophotometer to detect the nature of the biosurfactant obtained under the optimized conditions. Spectra were analyzed in transmittance mode within the wavelength range of $4000-400 \mathrm{~cm}^{-1}$ [22] Temperature stability of obtained biosurfactant was carried out in range of temperatures of $30-100{ }^{\circ} \mathrm{C}$ [12].

\section{Composition of biosurfactant assessment by GC/MS analysis}

Analytical grade N,O-Bis trifluoroacetamide (BSTFA) and acetic anhydride were purchased from SigmaAldrich, Poland. Other chemicals used, like methanol and hexane, were purchased from POCH Avantor, Poland. To $100 \mathrm{mg}$ of each sample, $0.1 \mathrm{~mL}$ of derivatization reagent BSTFA was added and mixed. After incubation at $60{ }^{\circ} \mathrm{C}$ for $30 \mathrm{~min}$, the sample was dissolved in $0.5 \mathrm{~mL}$ of hexane. The second series of the samples were analyzed via transmethylation with method described by Sasser [26]. The third derivatization method used was acetylation with $0.2 \mathrm{~mL}$ acetic anhydrous. The incubation conditions were as for BSTFA derivatization.

PEGASUS 4D GCxGC-TOFMS gas chromatograph (LECO Corp., St. Joseph, MI, USA) connected to a BPX5 (5\% phenyl equivalent, $28 \mathrm{~m} \times 0.25 \mathrm{~mm}$; $0.25 \mu \mathrm{m}$ ) capillary column (SGE Int., Melbourne, Australia) was used for qualitative analysis. Conditions of the GC-MS analysis: Helium as carrier gas (flow of $1.0 \mathrm{~mL} / \mathrm{min}$ ); ion source and transfer line temperature $-250{ }^{\circ} \mathrm{C}$; splitless injection; sample volume $1 \mu \mathrm{L}$; temperature program: oven temperature -40 to $-300^{\circ} \mathrm{C}$ at a rate of $12{ }^{\circ} \mathrm{C} / \mathrm{min}$, the oven temperature maintained for $15 \mathrm{~min}$. The acquisition rate was set at $10 \mathrm{spectra} / \mathrm{s}$.

\section{Emulsifying activity $\left(\mathrm{OD}_{500}\right)$ and emulsion index IE24}

To evaluate the emulsification capacity of the produced biosurfactant the emulsifying activity and emulsifying index IE24 were measured [27]. $2 \mathrm{ml}$ of crude biosurfactant solution was added into test tubes containing $2 \mathrm{ml}$ of diesel oil. The mixture was vortexed vigorously ( $2 \mathrm{~min}$ ) and left undisturbed for $24 \mathrm{~h}$. The emulsion index (IE24) was calculated by dividing the height of emulsion by the height of whole mixture, multiplying by 100 [14].

\section{Oil displacement test}

Oil displacement test was conducted according slightly modified Morikawa method [28]. $1 \mathrm{~mL}$ of mineral oil on the surface of $100 \mathrm{~mL}$ of water in a Petri dish with diameter of $15 \mathrm{~cm}$. Then, the $20 \mu \mathrm{L}$ of biosurfactant solution was delicately applied on the oil drop. The established clean zone was measured $30 \mathrm{~s}$ after the application of the biosurfactant solution compared with $1 \mathrm{ml}$ of distilled water as a negative control $[29,30]$.

\section{Surface tension analysis}

The interface properties of the biosurfactant was evaluated by measuring the equilibrium surface tension of the extract solutions at $21 \pm 1{ }^{\circ} \mathrm{C}$ using the du Nouy platinum ring technique with Easy Dyne K20 tensiometer (Krüss, Germany). The biosurfactant solutions were prepared using the deionised and ultrapurified Mili-Q water $(18.2 \mathrm{M} \Omega \mathrm{m})$.

\section{Thermostability}

The stability in various temperature variants $(30,37,55$, 75 and $100{ }^{\circ} \mathrm{C}$ ) was determined by preparing mixture of $2 \mathrm{ml}$ of oil and $2 \mathrm{ml}$ of 2 and $3 \%$ biosurfactant solutions and incubating them at the above-mentioned temperatures for $15 \mathrm{~min}$. After this time, the emulsion index was 
determined according to "Emulsifying activity (OD500) and emulsion index IE24" section.

\section{Effect of biosurfactant from endophytic $B$. pumilus $2 A$ on plant growth}

The seeds Phaseolus vulgaris L. (bean), Raphanus L. (radish), Beta vulgaris L. (beetroot) were surface sterilized with $1 \%(\mathrm{w} / \mathrm{v})$ sodium hypochlorite followed by three washings with sterile water. Ten sterilized seeds of each plant were placed on a cotton wool moistened with $20 \mathrm{~mL}$ of crude biosurfactant solution at concentration of 0.2 and $0.4 \%$ in a plastic beaker and incubated for 5 days at $25^{\circ} \mathrm{C}$ under a $12 \mathrm{~h}$ dark $/ 12 \mathrm{~h}$ light photoperiod. After this time the mass of grown plants was measured. Reference samples contained sterilized seeds incubated on moistened with sterile water cotton wool, incubated in the same conditions as described above.

\section{Data analysis}

Statistica 10.0 program was used for the calculation of mean values, standard deviations and the analysis of variance (single factor ANOVA). Analyses were carried out in triplicate. Tukey's test was used to test the differences between results represented as individual means and control mean \pm standard deviation. Significance was set at $\mathrm{p}=0.05$ and $p$-values $\leq 0.05$ were considered significant.

\section{Results and discussion}

Determination of optimum conditions for biosurfactant production by endophytic $B$. pumilus $2 \mathrm{~A}$

Primary optimum conditions for the production of surface-active compounds by endophytic bacteria Bacillus pumilus 2A, isolated from Chelidonium majus $\mathrm{L}$. were found using Taguchi method [20].

Quality characteristic (QC) of bigger-the-best was chosen. The main factor (carbon source, nitrogen source, $\mathrm{pH}$, amount of inoculum, temperature) effect plots are shown in Fig. 1. According to the results, the optimal levels of the tested factors for the production of biosurfactants were: A1B1C4D2E2 (i.e. A at level 1, B at level $1, \mathrm{C}$ at level 4, D at level 2 and $\mathrm{E}$ at level 2).Taking into consideration the contribution ratio of each factor it can be concluded that carbon source $(42.03 \%)$ and nitrogen source $(41.30 \%)$ have the highest impact on biosurfactant production by $\mathrm{B}$. pumilus $2 \mathrm{~A}$. $\mathrm{pH}$ of the culture broth has the least influence on the process (12.55\%).

Nonetheless, some of the obtained results for response variables (Table 3) are not consistent with doses envisioned from Taguchi method (Tables 1 and 2). In terms of the first factor (carbon source) the highest values

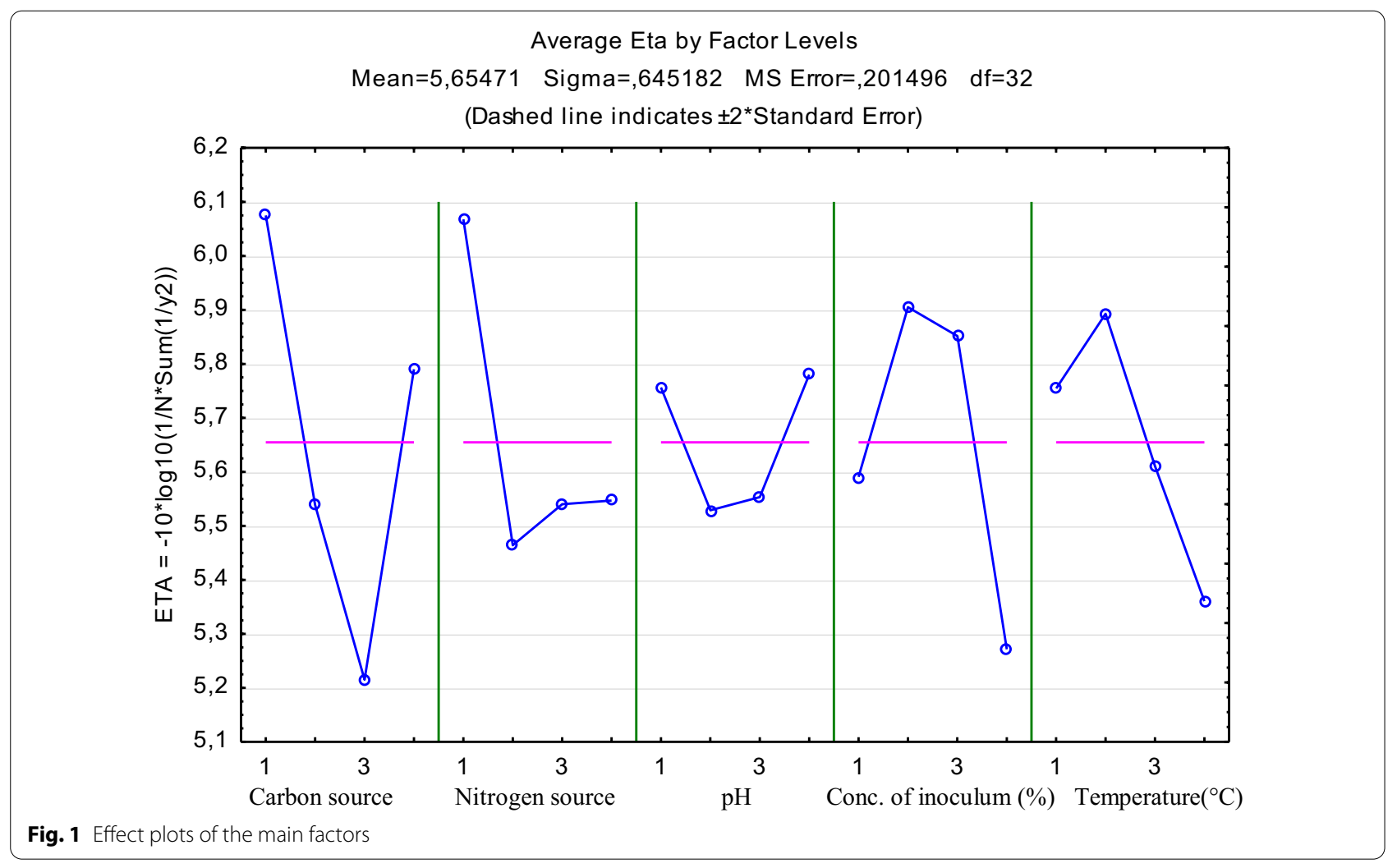


Table 3 Factors average effects on emulsifying activity $\left(\mathrm{OD}_{500}\right)$, emulsion index $(124)$ and the amount of biosurfactant

\begin{tabular}{llcc}
\hline Sample & Emulsifying activity $\mathbf{O D}_{\mathbf{5 0 0}}$ & Emulsion index $\mathbf{~ 2 4} \mathbf{( \% )}$ & Amount of biosurfactant (g/L) \\
\hline 1 & $1.839 \pm 0.036$ & $3.51 \pm 0.35$ & $3.65 \pm 0.43$ \\
2 & $2.145 \pm 0.033$ & $43.30 \pm 2.41$ & $7.13 \pm 0.11$ \\
3 & $1.783 \pm 0.012$ & $15.12 \pm 0.66$ & $3.25 \pm 0.33$ \\
4 & $2.085 \pm 0.034$ & $31.50 \pm 1.03$ & $6.46 \pm 0.18$ \\
5 & $1.824 \pm 0.017$ & $17.56 \pm 1.19$ & $2.35 \pm 0.04$ \\
6 & $1.835 \pm 0.033$ & $5.76 \pm 0.20$ & $1.97 \pm 0.16$ \\
7 & $1.807 \pm 0.023$ & $9.52 \pm 0.63$ & $2.87 \pm 0.11$ \\
8 & $2.004 \pm 0.032$ & $34.63 \pm 0.38$ & $4.48 \pm 0.13$ \\
9 & $1.926 \pm 0.043$ & $17.27 \pm 0.58$ & $2.96 \pm 0.22$ \\
10 & $1.874 \pm 0.027$ & $4.17 \pm 0.73$ & $1.16 \pm 0.09$ \\
11 & $2.052 \pm 0.033$ & $26.67 \pm 0.93$ & $6.15 \pm 0.48$ \\
12 & $1.903 \pm 0.056$ & $12.19 \pm 1.13$ & $4.98 \pm 0.39$ \\
13 & $1.739 \pm 0.076$ & $5.49 \pm 0.48$ & $2.06 \pm 0.28$ \\
14 & $1.934 \pm 0.062$ & $16.05 \pm 0.94$ & $5.43 \pm 0.16$ \\
15 & $1.837 \pm 0.039$ & $11.05 \pm 0.34$ & $1.56 \pm 0.05$ \\
\hline
\end{tabular}

of examined parameters (emulsifying activity $\left(\mathrm{OD}_{500}\right)$, emulsion index (IE24) and the amount of biosurfactant $(\mathrm{g} / \mathrm{L})$ were obtained for brewer's spent grain, as predicted from the Taguchi method. For this carbon source the yield of biosurfactant production by B. pumilus $2 \mathrm{~A}$ reached $7.125 \mathrm{~g} / \mathrm{L}$ with simultaneous highest emulsion index (IE24). Furthermore, these results indicate that the production of biosurfactant by endophytic Bacillus pumilus $2 \mathrm{~A}$ on brewery's spent grain is not only efficient (comparing to other tested substrates) but also that obtained biosurfactant has high emulsifying capacity (IE24=43.3\%).

In terms of nitrogen source, the highest values of examined parameters were obtained for ammonium nitrate, which was compatible with results predicted from Taguchi method. Saikia et al. [29] found that the highest biosurfactant production by Pseudomonas aeruginosa RS29 cultivated on glycerol were obtained when ammonium nitrate was used as nitrogen source.

Dikit et al. [31] also showed the highest yield of biosurfactant $(4.62 \mathrm{~g} / \mathrm{L})$ production by Agrobacterium rubi L5 using monosodium glutamate as nitrogen source. However, the authors indicated molasses in the amount of $5.0 \%(\mathrm{w} / \mathrm{v})$ as the optimal carbon source for biosurfactant production by examined bacteria. The results were similar to those obtained in the present research. While using molasses as the carbon source for B. pumilus 2A strain in the same $5 \% \mathrm{w} / \mathrm{v}$ concentration, the maximum yield of biosurfactant was $4.1 \mathrm{~g} / \mathrm{L}$. Our results showed that optimization of the carbon source is crucial for microbial production of biosurfactants. Under optimal conditions (using draff $(5 \% \mathrm{w} / \mathrm{v})$ as a carbon source and ammonium nitrate ( $1 \% \mathrm{w} / \mathrm{v})$ as nitrogen source), the production efficiency of B. pumilus 2A endophytic biosurfactant can reach $7.125 \mathrm{~g} / \mathrm{l}$.

As can be seen from the Table 2, in case of $\mathrm{pH}$ expected results are inconsistent with the Taguchi experimental design. According to Taguchi method the highest values of emulsifying activity, emulsion index and the amount of obtained biosurfactant should have been obtained for $\mathrm{pH}$ 9. However, high values of examined parameters were obtained also for $\mathrm{pH} 3,5$ and 7, depending on other investigated factors, like carbon and nitrogen source, inoculum concentration and temperature. The obtained results suggest that the $\mathrm{pH}$ of the culture broth does not have a significant influence on the biosurfactant production process by $B$. pumilus $2 \mathrm{~A}$.

Additionally, the results obtained for tested inoculum concentrations were consistent with those predicted from Taguchi method. As expected, the highest values of examined parameters were obtained for $5 \%$ of inoculum. Our results are consistent with those obtained by Fouda et al. [32], who examined seven different concentrations of inoculum $0.5,1,2,4,6,8$, and $10 \%(\mathrm{v} / \mathrm{v})$ to optimize biosurfactant production by Pseudomonas aeruginosa 4.2 and Bacillus cereus 2.3 bacteria strains. Their results showed that the inoculum of 4-6\% led to maximum production rates.

The highest values of emulsifying activity, emulsion index and the amount of biosurfactant were obtained when the process was carried out at the temperature of $30{ }^{\circ} \mathrm{C}$, which was supported by the Taguchi method. According to Bertrand et al. [33] the highest yield of biosurfactant production for Bacillus mycoides and Bacillus 
brevis strains may be obtained in the range of $35-40{ }^{\circ} \mathrm{C}$ However, the temperature of the bioprocess is closely related to the production costs. The results presented in this report show that the production of biosurfactant by B. pumilus $2 \mathrm{~A}$ at $30^{\circ} \mathrm{C}$ can take place at a lower temperature, which can lead to lower production costs.

However, Sahoo et al. [34] found that the temperature of $30{ }^{\circ} \mathrm{C}$ is the most suitable for the production of biosurfactants by Pseudomonas aeruginosa OCD1. Also, Najafi et al. [35] reported that the temperature of $30^{\circ} \mathrm{C}$ is optimal for the production of biosurfactants by Bacillus mycoides. These data correspond with our results placed in Table 3.

\section{Isolation and purification of biosurfactant in optimal conditions}

As mentioned before, according to the result obtained from the Taguchi method carbon source has the highest impact (42.03\%) on biosurfactant production by B. pumilus $2 \mathrm{~A}$. At the same time, ammonium nitrate as a nitrogen source, $\mathrm{pH}$ of $6,5 \% \mathrm{w} / \mathrm{v}$ of inoculum and temperature of $30^{\circ} \mathrm{C}$ turn out to be optimal for the process. Therefore, biosurfactant production was carried out using different carbon source as the only variable.

The bacterial growth, amount of obtained biosurfactant, emulsifying activity, emulsion index and oil displacement activity were analyzed (Table 4 ). The highest amount of biosurfactant $(6.8 \mathrm{~g} / \mathrm{L})$ was obtained for the brewer's spent grain used as a sole carbon source. Furthermore, in this variant of the process the highest growth of Bacillus pumilus 2A was observed. The use of brewer's spent grain as a carbon source resulted in the highest emulsifying activity $\left(\mathrm{OD}_{500} 2.07 \pm 0.069\right)$ and emulsion index (IE24 57.14 $\pm 0.007 \%$ ). Moreover, for this variant of experiment the highest oil displacement activity was noted. Moshtagh et al. [14] reported that the brewery waste in the concentration of $7 \% \mathrm{w} / \mathrm{v}$ can be used for biosurfactant production by Bacillus subtilis N3-1P.

However, it is difficult to compare their results with data obtained in the present study. Moshtagh et al. [14] used only two response variables (surface tension and emulsification index (IE24) in their optimization experiments and there is no information concerning the amount of obtained surfactant. Fooladi et al. [36] reported biosurfactant production by Bacillus pumilus 2IR. The strain was isolated from an oil field. However, on the basis of the amount of obtained biosurfactant $(1.08 \mathrm{~g} / \mathrm{L})$ authors claimed that investigated strain cannot be consider as good biosurfactant producer. These results are inconsistent with those obtained for endophytic Bacillus pumilus 2 A strain. In our experiments utilization of brewer's spent grain $(5 \% \mathrm{w} / \mathrm{v})$ resulted in the production of high amount of biosurfactant with very good emulsifying $(57.14 \pm 0.007)$ and oil displacement activity $(8 \mathrm{~cm})$. Therefore, the examines strain can be consider as a good biosurfactant producer. Farhan et al. [17] reported biosurfactant production by Bacillus sp. MTCC 5877 cultivated on different carbon sources e.g. glycerol, sodium citrate, glucose. Although, maximum emulsifying activity was high (75\%), oil displacement area obtained for the biosurfactant did not exceed $6 \mathrm{~cm}$. Studies on the physicochemical characteristics and stability were carried out using biosurfactant extracted from the culture performed in optimal conditions. Crude biosurfactant was obtained via acid precipitation followed by solvent extraction method.

\section{Physicochemical characteristics of biosurfactant FTIR analysis}

The structure of biosurfactant produced by endophytic Bacillus pumilus 2A has been studied by different analytical methods. FTIR technique was used to evaluate the molecular composition of biosurfactant. The absorption bands at $3292.42 \mathrm{~cm}^{-1}$ correspond to $-\mathrm{OH}$ stretching of carboxylic acid groups. The adsorption peaks at 1642 and $1743 \mathrm{~cm}^{-1}$ indicate the $\mathrm{C}=\mathrm{O}$ stretching and the presence of ester carbonyl group, respectively. The peaks at 1453.40 and $1124.36 \mathrm{~cm}^{-1}$ suggest the presence of stretching bands of carbon atoms with hydroxyl groups in the structure of sugar moiety [33]. Furthermore, bands at 1045.92 and $862.03 \mathrm{~cm}^{-1}$ was associated with the stretching vibrations of glycosidic linkage [37]. These results confirm that the surface active compound produced by Bacillus pumilus 2A belongs to the group of glycolipid biosurfactants.

Table 4 Summary of the biosurfactant production by B. pumilus 2A strain on different waste from food industry

\begin{tabular}{lrlllll}
\hline Carbon source & $\begin{array}{l}\text { Biosurfactant } \\
\text { amount } \mathbf{( m g / L )}\end{array}$ & Bacterial biomass (g/L) & pH post-culture & $\begin{array}{l}\text { Emulsifying } \\
\text { activity } \mathbf{O D}_{\mathbf{5 0 0}}\end{array}$ & Emulsion index (\%) & $\begin{array}{l}\text { Oil } \\
\text { displacement } \\
(\mathbf{c m}) \pm \mathbf{2} \mathbf{m m}\end{array}$ \\
\hline Molasses & $4068.57 \pm 81.37$ & $4.042 \pm 0.08$ & $6.83 \pm 0.2$ & $1.977 \pm 0.096$ & $30.77 \pm 0.104$ & 5 \\
Beet pulp & $650.01 \pm 32.50$ & $0.758 \pm 0.01$ & $7.00 \pm 0.2$ & $1.704 \pm 0.181$ & $31.09 \pm 0.075$ & 4 \\
Brewer's spent grains & $6800.02 \pm 136.0$ & $5.367 \pm 0.01$ & $8.20 \pm 0.2$ & $2.067 \pm 0.069$ & $57.14 \pm 0.007$ & 8 \\
Waste cooking oil & $641.67 \pm 32.08$ & $0.808 \pm 0.01$ & $6.13 \pm 0.2$ & $1.556 \pm 0.151$ & $34.17 \pm 0.137$ & 3.5 \\
\hline
\end{tabular}




\section{GC-MS analysis}

Chromatographic analysis performed after silanization of samples showed that the lipid moiety of B. pumilus 2A biosurfactant composed of 9,12-octadecadienoic (linoleic) acid methyl ester. This is the first report showing linoleic acid as the only hydrophobic part of Bacillus spp. biosurfactants. Clements et al. (2019) reported conjugated linoleic acid as a novel insecticide against Leptinotarsa decemlineata [38]. Due to the content of linolenic acid in the molecule, the biosurfactant produced by $B$. pumilus 2 A may also have potential use as a bioinsecticide. However, this phenomenon requires further research. Moussa and Azeiz [38] described lipopeptide produced by Rhodococcus equi which lipid moiety consisted of $28.7 \%$; palmitic oleic acid, $15.4 \%$ 10-methyl stearic, $12.09 \%$ 6-octadecenoic acid, and 17.81\% linoleic acid. Additionally, small amount of glycerol and monoglycerides were observed. Analysis of the hydrophilic part of biosurfactant revealed a three-sugar glycolipid structure consisting of D-glucose, and D-arabinose and D-xylose.

\section{Surface tension}

The dependence of surface tension and the biosurfactant concentration was presented in Fig. 2. The highest concentration providing homogeneous solution was $5000 \mathrm{mg} / \mathrm{L}$. At this concentration the surface tension decreased to $47.7 \mathrm{mN} / \mathrm{m}$. With decreasing concentration the surface tension increased up to $53.8 \mathrm{mN} / \mathrm{m}$ at $1000 \mathrm{mg} / \mathrm{L}$ and $63.6 \mathrm{mN} / \mathrm{m}$ at $250 \mathrm{mg} / \mathrm{L}$.

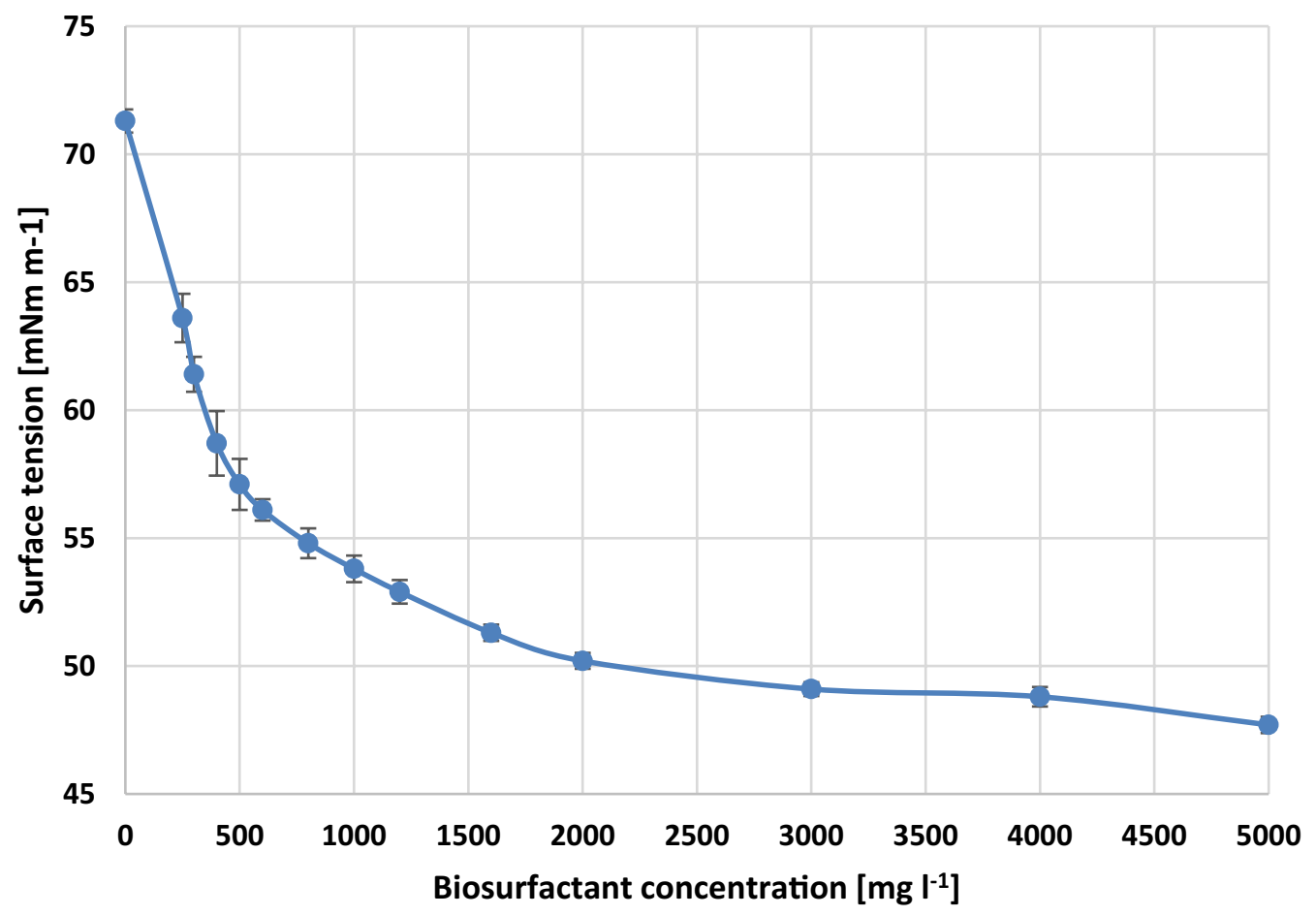

Fig. 2 Surface tension at different concentrations of biosurfactant produced by endophytic Bacillus pumilus 2A on brewer's spent grain

Table 5 Thermostability of biosurfactant solution produced by Bacillus pumilus $2 \mathrm{~A}$ on brewer's spent grain

\begin{tabular}{|c|c|c|c|c|c|c|c|c|}
\hline \multirow{3}{*}{$\begin{array}{l}\text { Temperature } \\
\left({ }^{\circ} \mathrm{C}\right)\end{array}$} & \multirow{2}{*}{\multicolumn{2}{|c|}{$\begin{array}{l}\text { Emulsion index IE24 } \\
\text { Concentration (\% w/v) }\end{array}$}} & \multirow{2}{*}{\multicolumn{2}{|c|}{$\begin{array}{l}\text { Emulsion index IE48 } \\
\text { Concentration (\% w/v) }\end{array}$}} & \multirow{2}{*}{\multicolumn{2}{|c|}{$\begin{array}{l}\text { Emulsion index IE96 } \\
\text { Concentration (\% w/v) }\end{array}$}} & \multirow{2}{*}{\multicolumn{2}{|c|}{$\begin{array}{l}\text { Emulsion index IE456 } \\
\text { Concentration (\% w/v) }\end{array}$}} \\
\hline & & & & & & & & \\
\hline & 2 & 3 & 2 & 3 & 2 & 3 & 2 & 3 \\
\hline 30 & $69.62 \pm 1.30$ & $66.26 \pm 0.91$ & $64.41 \pm 1.59$ & $66.11 \pm 0.78$ & $65.07 \pm 0.61$ & $64.96 \pm 0.05$ & $59.94 \pm 0.09$ & $56.26 \pm 0.93$ \\
\hline 37 & $63.26 \pm 0.75$ & $69.96 \pm 1.68$ & $63.08 \pm 0.50$ & $69.59 \pm 2.14$ & $62.57 \pm 0.09$ & $65.28 \pm 1.58$ & $56.29 \pm 0.21$ & $62.22 \pm 0.61$ \\
\hline 55 & $68.02 \pm 0.17$ & $76.45 \pm 1.22$ & $68.14 \pm 0.03$ & $69.52 \pm 1.07$ & $63.61 \pm 0.50$ & $61.64 \pm 1.24$ & $61.73 \pm 0.56$ & $57.47 \pm 0.68$ \\
\hline 75 & $75.51 \pm 0.50$ & $66.59 \pm 1.29$ & $71.02 \pm 1.83$ & $66.62 \pm 1.23$ & $67.70 \pm 0.79$ & $60.51 \pm 1.08$ & $62.74 \pm 0.24$ & $55.39 \pm 0.72$ \\
\hline 100 & $64.00 \pm 0.31$ & $57.12 \pm 1.36$ & $58.96 \pm 0.11$ & $53.64 \pm 1.53$ & $46.81 \pm 1.02$ & $43.46 \pm 1.04$ & $45.68 \pm 1.32$ & $41.20 \pm 0.64$ \\
\hline
\end{tabular}



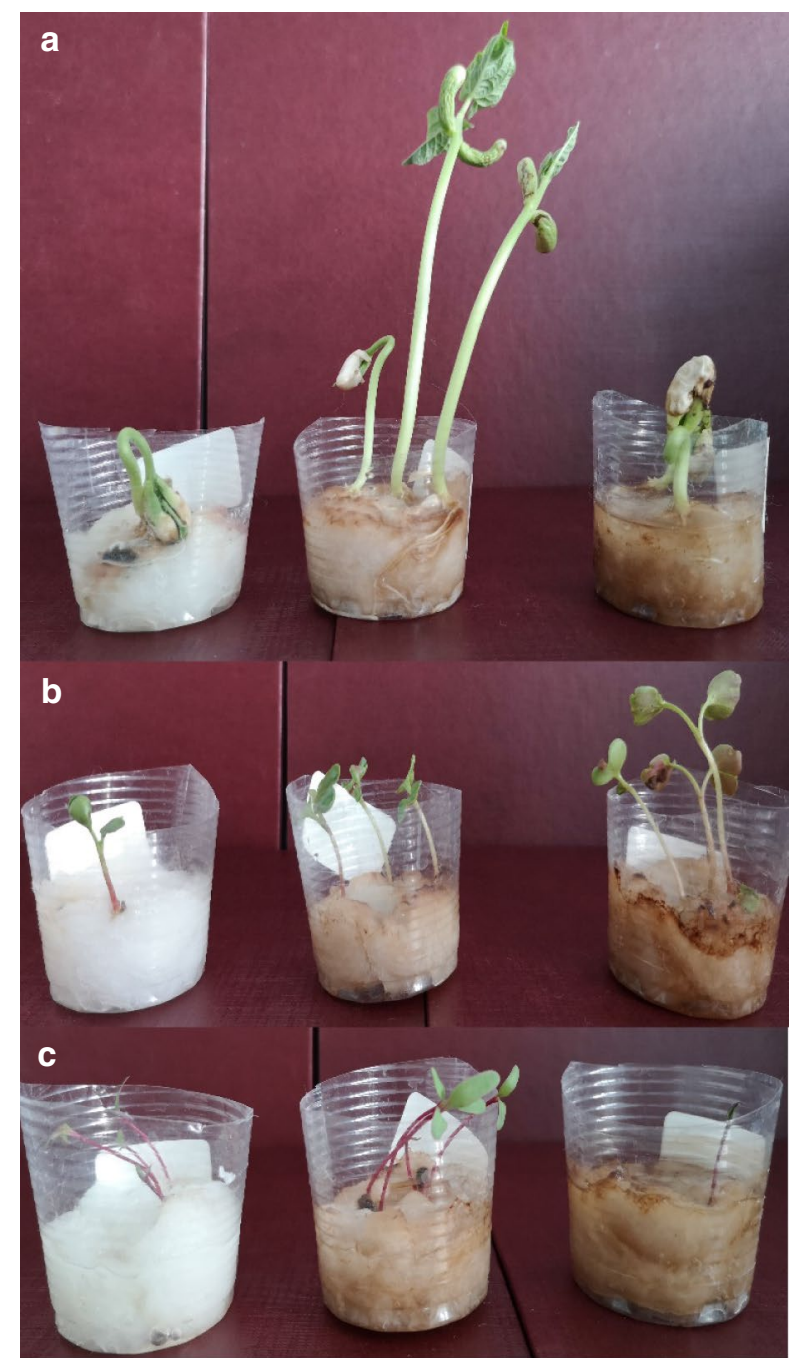

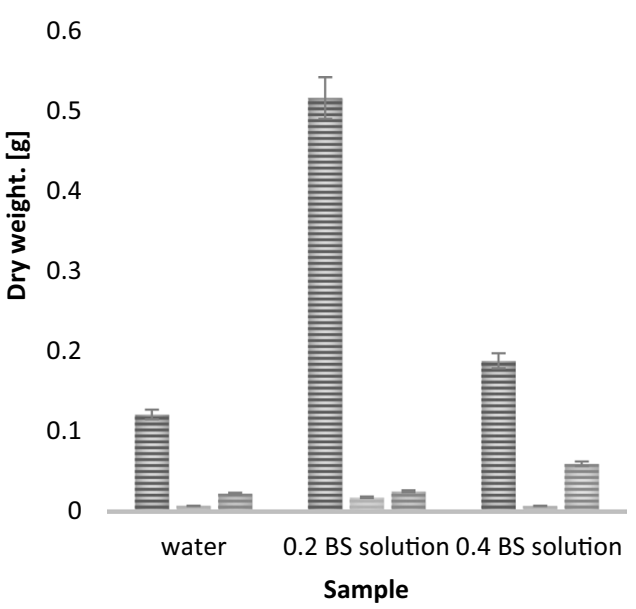

EPhaselous vulgaris $\mathrm{L}$. $\equiv$ Beta vulgaris $\equiv$ Raphanus $\mathrm{L}$.

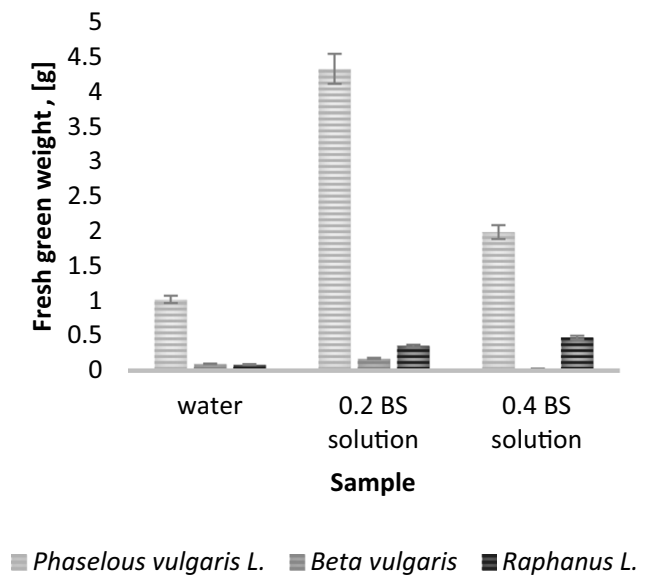

Fig. 3 Effect of biosurfactant obtained from endophytic Bacillus pumilus 2A cultivated on brewer's spent grain on plant growth promotion, fresh green weight and dry weight of a Phaselous vulgaris L. (bean), b Raphanus L. (radish); c Beta vulgaris L. (beetroot)

Similar results were obtained by Oliveira and GarciaCruz [39] who studied the biosynthesis of biosurfactant by Bacillus pumilus on vinasse and waste frying oil. The best reduction in surface tension of obtained biosurfactant was $45 \mathrm{mN} / \mathrm{m}$. Also, Bento et al. [40] obtained $49.5 \mathrm{mN} / \mathrm{m}$ surface tension for biosurfactant produced by Bacillus pumilus on yeast extract.

\section{Thermostability}

After 15 min of incubation samples were cooled at room temperature and the emulsion index (IE24) was measured as an indicator of biosurfactant stability [12].

The effect of temperature on biosurfactant stability revealed that Bacillus pumilus 2A produces stable surface active agent in high range of temperature 30-100 ${ }^{\circ} \mathrm{C}$ (Table 5). The emulsion index fluctuates slightly depending on the temperature, although surprisingly its highest values were recorded at $75{ }^{\circ} \mathrm{C}$ for $2 \%$ solution of biosurfactant. For the higher concentration (3\%) of the biosurfactant solution, the highest values of the emulsion index $(76.45 \%)$ were obtained after $24 \mathrm{~h}$. However, apart from the results obtained at $100^{\circ} \mathrm{C}$, only slight differences in the stability of the 2 and 3\% biosurfactant solutions were observed. Similar phenomenon was noted by Moussa and Azeiz [39]. They observed only slight fluctuations in the stability of biosurfactants produced by Rhodococcus equi and Bacillus methylothrophicus strains in the temperature range $20-120{ }^{\circ} \mathrm{C}$. Hatef and Khudeir [41] found during their experiments that the biosurfactant produced by the Pseudomonas putida PS6 strain maintains stability in the temperature range of $20-70{ }^{\circ} \mathrm{C}$, although with increasing temperature over 
$70{ }^{\circ} \mathrm{C}$ this stability clearly decreases. The highest stability was noted after $24 \mathrm{~h}\left(\mathrm{IE}_{24}=75 \%\right)$ and decreased in time. Nevertheless, even after nineteen days biosurfactant maintain almost $82 \%$ of its stability $\left(\mathrm{IE}_{496}=62 \%\right)$. According to Ruggeri et al. [42] the strain can be considered as biosurfactant producer if surface tension is reduced to $<50 \mathrm{mN} / \mathrm{m}$ and and/or at least $50 \%$ emulsification is observed after $24 \mathrm{~h}$ [42]. Bacillus pumilus $2 \mathrm{~A}$ cultivated on brewer's spent grain demonstrated both of those features, thus it suggests that the strain can be used for biosurfactant production.

\section{Effect of biosurfactant from endophytic $B$. pumilus $2 A$ on plant growth}

We have previously described the positive impact of biosurfactant produced by B. pumilus $2 \mathrm{~A}$ on the germination and seeding of Sorghum saccharatum, Sinapis alba and Lepidium sativum on soil contaminated with hydrocarbons, using phytotoxicity tests [16]. In this study biosurfactant from Bacillus pumilus 2A obtained under optimized conditions was used to investigate its effect on plant growth in in vitro experiments (Fig. 3).The use of biosurfactant solutions resulted in enhanced growth of examined plants. The greatest stimulation of plant growth was obtained for biosurfactant solution used in $0.2 \%$ concentration. Comparing to control samples using $0.2 \%$ of biosurfactant solution resulted in 4 times, 4 times and 2 times higher growth for bean, radish and beetroot, respectively. For higher concentration of glycolipid lower stimulation of growth was observed. Research on the impact of biosurfactants on plant growth is scarce. It is assumed that microbial surfactants may indirectly promote plant growth by increasing the bioavailability of hydrophobic compounds to microorganisms living in the rhizosphere [20,43,44]. The weaker effect of plant growth stimulation observed at a higher concentration of B. pumilus $2 \mathrm{~A}$ biosurfactant may result from an increase in the amount of hydrophobic compounds in the environment, which rhizosphere microorganisms were unable to assimilate, or from the release of compounds adsorbed in the soil, which inhibited the growth of these microorganisms. Also, higher concentration of biosurfactants may cause damage to root plant tissue [45]. Most of the research on the effect of biosurfactants on plant growth concerns environments polluted with hydrocarbons or heavy metals.

Our research shows the possibility of using biological surfactants as ecological, inexpensive and easy to obtain agents that can be used in agriculture to promote plant growth. However, more research is still required to explain the mechanism of the effect of biosurfactants on plant growth.

\section{Conclusion}

To conclude, endophytic Bacillus pumilus 2A produce glycolipid biosurfactant with high and long term thermostability, what makes it useful for many purpose including food processing. The use of brewer's spent grain as the sole carbon source makes the production of biosurfactants profitable, and from an environmental point of view, it is an environmentally friendly way to remove food processing by-products. Glycolipid produced by endophytic Bacillus pumilus 2A significantly improve growth of Phaseolus vulgaris L. (bean), Raphanus L. (radish), Beta vulgaris L. (beetroot). Our results provide new insight to the possible use of glycolipids as plant growth promoting agents.

\section{Acknowledgements \\ Authors are grateful to the Institute of Molecular and Industrial Biotechnology, Lodz University of Technology, Poland for financial assistances for the present} studies.

\section{Authors' contributions}

Conceptualization, OM-M and PD; Data curation, OM-M and PD; Formal analysis, PD, WS, AP; Investigation, OM-M and PD; Methodology, OM-M and PD;

Project administration, OM-M and PD; Resources, PD; Supervision, OM-M and PD; Validation, TA; Visualization, OM-M and PD; Writing —original draft, OM-M and PD. All authors read and approved the final manuscript.

\section{Funding}

This research received no external funding.

\section{Availability of data and materials}

The data collected upon which this article is based upon are all included in this manuscript.

\section{Ethics approval and consent to participate}

No animals or human subjects were used in the above research.

\section{Consent for publication}

Our manuscript does not contain any individual data in any form.

\section{Competing interests}

The authors declare that they have no competing interests.

\section{Author details}

${ }^{1}$ Institute of Molecular and Industrial Biotechnology, Faculty of Biotechnology and Food Science, Lodz University of Technology, Stefanowskiego 4/10, 90-924 Łódź, Poland. ${ }^{2}$ Department of Organic Chemistry, Faculty of Chemical Technology, Poznan University of Technology, Berdychowo 4, 60-965 Poznań, Poland. ${ }^{3}$ Polytechnic Faculty, Food Technology and Human Nutrition, State University of Applied Sciences, Nowy Świat 4 st., 62-800 Kalisz, Poland.

Received: 2 October 2020 Accepted: 27 January 2021

Published online: 08 February 2021

References

1. Myers D, Surfactant science and technology, USA, Wiley-Interscience, Surf. Sci. Technol. 2005.

2. Ying G. Fate, behavior and effects of surfactants and their degradation products in the environment. Environ Int. 2006;32:417-31.

3. Ash M, Ash I, Handbook of Industrial Surfactants Synapse Information Resources, Inc., Endicott, New York, 2010.

4. A. Saika, T. Fukuoka, S. Mikome, Y. Kondo, H. Habe, T. Morita, Screening and isolation of the liamocin-producing yeast Aureobasidium 
melanogenum using xylose as the sole carbon source, J. Biosci. Bioeng., in press; 2019). Doi:https://doi.org/10.1016/j.jbiosc.2019.10.010.

5. Hayes D, Solaiman D, Ashby R. Biobased Surfactants. 2nd ed. Published by Elsevier: AOCS Press; 2019

6. Olkowska E, Polkowska Z, Namiésnik J. Analytical procedures for the determination of surfactants in environmental samples. Talanta. 2012:88:1-13

7. Scott MJ, Jones MN. The biodegradation of surfactants in the environment Biochim. Biophys Acta. 2000;1508:235-51.

8. Kaur G, Wang H, To MH, Roelants SLKW, Soetaert W, Lin CSK. Efficient sophorolipids production using food waste. J Clean Prod. 2019;232:1-11. https://doi.org/10.1016/j.jclepro.2019.05.326.

9. Jiménez-Peñalver P, Castillejos M, Koh A, Gross R, Sánchez A, Font X, Gea T. Production and characterization of sophorolipids from stearic acid by solid-state fermentation, a cleaner alternative to chemical surfactants. J Clean Prod. 2018;172:2735-47. https://doi.org/10.1016/j.jclep ro.2017.11.138.

10. Pi Y, Bao M, Liu Y, Lu T, He R. The contribution of chemical dispersants and biosurfactants on crude oil biodegradation by Pseudomonas sp. LSH-7'. J Clean Prod. 2017;153:74-82. https://doi.org/10.1016/j.jclepro.2017.03.120.

11. Zhao Y, Han F, Abdelaziz IIM, Liu X, Ghazali KH, Mishra P. Application of biosurfactant tea saponin in flotation separation for ternary plastic mixtures: Statistical optimization and mechanism analysis. J Clean Prod. 2019. https://doi.org/10.1016/j.jclepro.2019.06.002.

12. Patil S, Pendse A, Aruna K. Studies on optimization of biosurfactant production by Pseudomonas aeruginosa F23 isolated from oil contaminated soil sample. Int J Curr Biotech. 2014;2(4):20-30.

13. Vea EB, Romeo $D$, Thomsen M. Biowaste valorisation in a future circular bioeconomy. Procedia CIRP. 2018;69:591-6.

14. Moshtagh B, Hawboldt K, Zhang B. Optimization of biosurfactant production by Bacillus subtilis N3-1P using the brewery waste as the carbon source. Environ Technol. 2019;40(25):3371-80.

15. Gautam G, Mishra V, Verma P, Pandey AK, Negi S. A cost effective strategy for production of bio-surfactant from locally isolated Penicillium chrysogenum SNP5 and its applications. J Bioprocess Biotech. 2014. https://doi. org/10.4172/2155-9821.1000177.

16. Velioglu Z, Urek RO. Optimization of cultural conditions for biosurfactant production by Pleurotus djamor in solid state fermentation. J Biosci Bioeng. 2015;120(5):526-31.

17. Farhan A, Gunjan G, Gnansounou E, Sangeeta N. Biosurfactant production through Bacillus sp. MTCC 5877 and its multifarious applications in food industry. Biores Tech. 2016;213:262-9.

18. N.V. Malfanova, Endophytic bacteria with plant growth promoting and biocontrol abilities. Ph.D. thesis, Leiden: Leiden University, 2013.

19. Pisarska K, Pietr SJ. Bakterie endofityczne-ich pochodzenie i interakcje z roślinami. Post Mikrobiol. 2014;53:141-51 (in polish).

20. O. Marchut-Mikolajczyk, P. Drożdżyński, D. Pietrzyk, T. Antczak, Biosurfactant production and hydrocarbon degradation activity of endophytic bacteria isolated from Chelidonium majus L., Microb Cell Fact., 17, 171 (2018) doi: https://doi.org/10.1186/s12934-018-1017-5.

21. Rabiey M, Hailey LE, Roy SR, Grenz K, Al-Zadjali MAS, Barret GA, Jackson RW. Endophytes vs tree pathogens and pests: can they be used as biological control agents to improve tree health? Eur J Plant Pathol. 2019;155:711-29. https://doi.org/10.1007/s10658-019-01814-y.

22. Marchut-Mikołajczyk O, Drożdżyński P, Januszewicz B, Domański J, Wrześniewska-Tosik K. Degradation of ozonized tire rubber by aniline Degrading Candida methanosorbosa BP6 strain. J Haz Mat. 2019;367:8-14.

23. Sumiardi A, Mangunwardoyo W, Hudiyono S, Susilaningsih D. Biosurfactant characterization of bacterial consortium from soil contaminated hydrocarbon in Cepu Area, Central Java. Indonesia Int J Sci Res Publ. 2012;2(7):1-7.

24. Dubois M, Gilles EKA, Hamilton JK, Rebers PA, Smith F. Calorimetric Dubois Method for Determination of Sugar and Related Substances. Anal Chem. 1956:28(3):350-6

25. Bradford MM. A rapid and sensitive method for quantitation of microgram quantities of protein utilizing the principle of protein-dye binding. Anal Biochem. 1976;72:248-54.

26. Sasser MJ. Identification of bacteria by gas chromatography of cellular fatty acids, Technical note 101. Newark, DE: Microbial ID Inc; 1990.

27. Pearce KN, Kinsela JE. Emulsifying properties of proteins: evaluation of a turbidimetric. Tech J Agric Food Chem. 1978;26(3):716-23.
28. Morikawa M, Hirata Y, Imanaka T. A Study on the structure-function relationship of lipopeptides biosurfactants. Biochim Biophys Acta. 2000;1488:211-8

29. Saikia RR, Deka S, Deka M, Sarma H. Optimization of environmental factors for improved production of rhamnolipid biosurfactant by Pseudomonas aeruginosa RS29 on glycerol. J Basic Microbiol. 2012;52(4):446-57.

30. A. Sharma, G. Soni, G. Kaur, J. Kaur, Study on biosurfactant production in Lactobacillus and Bacillus sp., Int.J.Curr Microbiol. App.Sci, 3(11) (2014) 723-733.

31. Dikit P, Maneerat S, Saimmai A. Production and application of biosurfactant produced by Agrobacterium rubi L5 isolated from mangrove Sediments. Appl Mech Mat. 2019;886:98-104.

32. Fouda A, El-Gamal M, Hussein E, Radwan A. Optimization and improvement of biosurfactant production for Pseudomonas aeruginosa 4.2 and Bacillus cereus 2.3 strains isolated from oily polluted soil sample. Int J Adv Res Biol Sci. 2016;3:76-87.

33. Bertrand B, Martinez-Morales F, Rosas-Galvan NS, Morales-Guzman D, Trejo-Hernandez MR. Statistical design, a powerful tool for optimizing biosurfactant production: a review. Colloids Interfaces. 2018;2(3):36. https ://doi.org/10.3390/colloids2030036.

34. Sahoo S, Datta S, Biswas D. Optimization of culture conditions for biosurfactant production from Pseudomonas aeruginosa OCD1. J Adv Scient Res. 2011;2:32-6.

35. Najafi AR, Rahimpour MR, Jahanmiri AH, Roostaazad R, Arabian D, Ghobadi Z. Enhancing biosurfactant production from an indigenous strain of by optimizing the growth conditions. Chem Engin Journal. 2010;163:188-94

36. Fooladi TP, Abdeshahian P, Moazami N, Soudi MH, Kadier A, Yusoff WMW, Hamid AA. Enhanced biosurfactant production by Bacillus pumilus 2IR in Fed-batch fermentation using 5-L BIOREACTOR. Iran J Sci Technol Trans A Sci. 2018;42:3-11.

37. Singh P, Tiwary BN. Isolation and characterization of glycolipid biosurfactant produced by a Pseudomonas otitidis strain isolated from Chirimiri coal mines. India Bioresour Bioprocess. 2016;3:42.

38. Clements J, Groves R, Cava JA, Barry C, Chapman S, Olson J. Conjugated linoleic acid as a novel insecticide targeting the agricultural pest Leptinotarsa decemlineata. PLoS ONE. 2019;14:e0220830. https://doi. org/10.1371/journal.pone.0220830.

39. Moussa LA, Azeiz AZA. Identification and characterization of biosurfactants produced by Rodococcus equi and Bacillus methlyotrophicus. J Biol Chem Environ Sci. 2013:8(2):341-58.

40. Oliveira J, Garcia-Cruz C. Properties of a biosurfactant produced by Bacillus pumilus using vinasse and waste frying oil as alternative carbon sources. Braz Arch Biol Technol. 2013;56:155-60.

41. Hatef ZH, Khudeir SH. Characterization of biosurfactant produced by Pseudomonas putida PS6 isolated from contaminated soil. J Pharm Biol Sci. 2017;12(6):13-8.

42. Ruggeri C, Franzetti A, Bestetti G, Caredda P, La Colla P, Pintus M, Sergi S, Tamburini E. Isolation and characterisation of surface active compoundproducing bacteria from hydrocarbon-contaminated environments. Int Biodeterior Biodegradation. 2009;63:936-42.

43. Saraf M, Pandya U, Thakkar A. Role of allelochemicals in plant growth promoting rhizobacteria for biocontrol of phytopathogens. Microbiol Res. 2014. https://doi.org/10.1016/j.micres.2013.08.009.

44. Khan MSA, Singh B, Cameotra SS. Biological applications of biosurfactants and strategies to potentiate commercial production biosurfactants. Prod Util Processes Technol Econ. 2015;1 (1):269-95.

45. Sachdev DP, Swaranjit SC. Biosurfactants in agriculture. Appl Microbiol And Biotechnol. 2013;97(3):1005-16.

46. Bento FM, Camargo FAO, Okeke B, Frankenberger-Júnior WT. Bioremediation of soil contaminated by diesel oil. Braz J Microbiol. 2003;34(suppl 1):65-8.

47. Dadrasnia A, Ismail S. Biosurfactant production by Bacillus salmalaya for lubricating oil solubilization and biodegradation. Int J Environ Res Public Health. 2015;12(8):9848-63.

\section{Publisher's Note}

Springer Nature remains neutral with regard to jurisdictional claims in published maps and institutional affiliations. 